\title{
KAJIAN MODAL SOSIAL PADA KELOMPOK TANI DI DESA TUMANI KECAMATAN MAESAAN KABUPATEN MINAHASA SELATAN (Kelompok Tani Esa Waya dan Kelompok Tani Sinar Mas)
}

\author{
Youdi Mamahit \\ Welson M. Wangke \\ Nortje M. Benu
}

\begin{abstract}
The objective of research is to examine Social Capital based on the elements of norm, network, trust, reciprocity, and values of the Esa Waya and Sinar Mas farmer groups. This research was conducted from May 2016 until July 2016, started from preparation until report compilation. The data used were in the form of primary data and secondary data. This research was carried out with purposive sampling technique. Fifty percent members of the population every farmer group. They are 11 members of Esa Waya group and 8 members of Sinar Mas group. Data analysis was done descriptively, served with using the table and then be interpreted. The result showed that, those elements of norm, network, trust, reciprocity, and values, social capital able to improve the existence and solidarity on the Esa Waya farmer group. The opposite, social capital has been reduced even has no longer on the Sinar Mas farmer group so that Sinar Mas farmer group was not progressed. In addition, the other factor is the age of Esa Waya group younger then Sinar Mas group. The education levels of the Esa Waya group higher than Sinar Mas group.
\end{abstract}

Key Words: Social Capital, Farmer Group,

\begin{abstract}
ABSTRAK
Penelitian ini bertujuan untuk mengkaji modal sosial berdasarkan norma, jaringan, kepercayaan, hubungan timbal balik, dan nilai-nilai sebagai unsur-unsur modal sosial pada Kelompok Tani Esa Waya dan Kelompok Tani Sinar Mas. Penelitian ini dilaksanakan pada bulan Mei 2016 hingga Juli 2016, mulai dari persiapan sampai penyusunan laporan. Data yang digunakan adalah data Primer dan sekunder. Penelitian ini dilakukan dengan teknik Purposive Sampling, dengan jumlah sampel yang diambil sebanyak 50\% dari anggota kelompok yakni kelompok tani Esa Waya 11 responden dan Kelompok Tani Sinar Mas 8 responden. Analisis data dilakukan secara deskriptif yang disajikan dengan menggunakan tabel kemudian diinterpretasikan. Hasil penelitian ini menunjukan bahwa unsur-unsur modal sosial yaitu norma, jaringan, kepercayaan, hubungan timbal balik, dan Nilai-nilai telah mampu meningkatkan eksistensi serta kekompakan pada kelompok tani Esa Waya. Sebaliknya pada kelompok tani Sinar Mas Unsur-unsur modal sosial sudah berkurang bahkan tidak ada lagi dalam kelompok sehingga menyebabkan kelompok Sinar Mas tergolong kurang aktif. Faktor lainnya yaitu tingkat umur kelompok tani Esa Waya yang lebih muda dan tingkat pendidikan yang lebih tinggi dibandingkan kelompok tani Sinar Mas.
\end{abstract}

Kata Kunci: Modal Sosial, Kelompok Tani 


\section{PENDAHULUAN}

\section{Latar Belakang}

Indonesia adalah Negara agraris dengan kondisi alam yang mendukung, lahan yang luas, keragaman hayati yang melimpah, serta beriklim tropis. Realita sumberdaya alam seperti ini seharusnya mampu membangkitkan Indonesia menjadi negara yang makmur dan tercukupi kebutuhan pangan seluruh warganya. Meskipun belum terpenuhi, pertanian menjadi salah satu sektor yang memiliki peran sangat nyata sebagai sumber mata pencaharian penduduk karena lebih dari 31 juta jiwa penduduk indonesia adalah berprofesi sebagai petani di sektor pertanian, demikian data yang dilansir oleh badan pusat statistik. Begitu juga dengan penduduk di Provinsi Sulawesi Utara khususnya Kabupaten Minahasa Selatan.

Sebagian besar penduduk Kabupaten Minahasa Selatan menggantungkan hidupnya pada sektor pertanian. Lebih dari 37 ribu penduduk Kabupaten Minahasa Selatan adalah berprofesi sebagai petani di sektor pertanian.

Kebijakan yang ditempuh Pemerintah Kabupaten Minahasa Selatan untuk mewujudkan tujuan pembangunan nasional diantaranya adalah dengan peningkatan kehidupan ekonomi yang dilakukan melalui pembangunan pertanian. Salah satu kebijakan mendasar untuk mengatasi masalah dalam pertanian adalah membentuk kelompok tani.

Kelompok tani adalah kumpulan para petani yang terikat secara formal atas dasar keserasian, kesamaan kondisi lingkungan (sosial, ekonomi, sumberdaya), keakraban, kepentingan bersama dan saling mempercayai, serta mempunyai pimpinan untuk mencapai tujuan bersama. Pembentukan kelompok tani merupakan suatu usaha pembangunan pertanian yang berfungsi untuk memperlancar hasil pertanian dan memberikan wadah yang kokoh di pedesaan dan merupakan tempat untuk memperkuat kerjasama diantara para petani dalam kelompok untuk menghadapi berbagai ancaman, tantangan, hambatan dan gangguan.

Desa Tumani merupakan salah satu desa yang terletak di Kecamatan Maesaan Kabupaten Minahasa Selatan terletak di daerah pegunungan yang sebahagian besar penduduknya bermata pencaharian sebagai petani dan tergabung dalam kelompokkelompok tani. Mayoritas petani di desa ini bercocok tanam padi, akan tetapi ada juga petani yang menanam tanaman lainnya seperti jagung, sayur-sayuran, umbi-umbian dan lainlain. Terdapat 24 kelompok tani di Desa Tumani yang anggotanya masing-masing berbeda. Akan tetapi berdasarkan keterangan yang diperoleh dari Balai Penyuluhan Pertanian Perikanan dan Kehutanan (BP3K) Kecamatan Maesaan diantara ke 24 kelompok tani di Desa Tumani hanya 1 kelompok tani yang dinilai aktif yaitu Kelompok Tani Esa Waya. Dan 1 kelompok tani lainnya yaitu Kelompok Tani Sinar Mas dinilai kurang aktif dalam usaha kelompok taninya.

Kelompok Tani Esa Waya terbentuk pada tahun 2006 yang beranggotakan 22 orang dan pengurus 3 orang. Sedangkan kelompok tani Sinar Mas terbentuk pada Tahun 1997 yang berangotakan 16 orang

Keberlangsungan kelompok tani membutuhkan adanya modal (capital) yang merupakan pondasi suatu usaha. Khususnya modal ekonomi atau finansial (financial capital). Selain modal finansial, modal yang dapat dijadikan untuk investasi di masa depan adalah modal sosial (Suharto, 2007).

Modal sosial dapat didefinisikan sebagai serangkaian nilai dan norma informal yang dimilki bersama diantara para anggota suatu kelompok masyarakat yang memungkinkan terjadinya kerjasama diantara mereka (Fukuyama, 2002).

Berdasarkan latar belakang yang diuraikan maka penting untuk mengkaji modal sosial dalam Kelompok Tani Esa Waya dan Kelompok Tani Sinar Mas di Desa Tumani Kecamatan Maesaan Kabupaten Minahasa Selatan sebagai perbandingan. Mengingat 
kelompok tani Esa Waya adalah Kelompok Tani yang cukup berkembang diantara kelompok tani lainnya di Desa Tumani dan Kelompok Tani Sinar Mas merupakan kelompok yang kurang berkembang.

\section{Rumusan Masalah}

Bagaimana modal sosial yang terdapat pada Kelompok Tani Esa Waya dan Kelompok Tani Sinar Mas.

\section{Tujuan dan Manfaat Penelitian}

penelitian ini bertujuan untuk mengkaji modal sosial pada Kelompok Tani Esa Waya dan Kelompok Tani Sinar Mas di Desa Tumani Kecamatan Maesaan Kabupaten Minahasa Selatan.

Penelitian ini diharapkan dapat memberikan kontribusi kepada petani terlebih khusus anggota kelompok tani Esa Waya mengenai Modal Sosial yang terdapat dalam Kelompok Tani Esa Waya dan Kelompok Tani Sinar Mas. Dan bahan masukan bagi kelompok Tani lainnya yang terdapat di Desa Tumani.

\section{METODOLOGI PENELITIAN}

\section{Waktu dan Lokasi Penelitian}

Penelitian ini dilaksanakan di Desa Tumani Kecamatan Maesaan Kabupaten Minahasa Selatan selama 3 bulan mulai dari bulan Mei 2016 sampai bulan Juli 2016 mulai dari persiapan, pengambilan data sampai pada penyusunan laporan hasil penelitian.

\section{Metode Pengumpulan Data}

Metode pengumpulan data dalam penelitian ini menggunakan data primer dan data sekunder. Data primer diperoleh dari wawancara langsung menggunakan daftar pertanyaan dan data sekunder yang diperoleh dari Pemerintah Desa Tumani dan Balai Penyuluhan Pertanian Perikanan dan Kehutanan (BP3K) kecamatan Maesaan.

\section{Konsep Pengukuran Variabel}

\section{Modal Sosial}

1) Norma

sekumpulan aturan yang diharapkan dipatuhi dan diikuti oleh anggota masyarakat pada suatu etnits sosial tertentu. Kriteria Indikator pengukurannya sebagai berikut :
a. Peraturan : Peraturan yang tegas terhadap semua anggota kelompok
b. Sanksi : Sanksi yang tegas diberikan kepada setiap anggota kelompok yang melakukan pelanggaran
c. Keadilan : Pengambilan keputusan yang bijaksana diberikan oleh ketua kelompok tani kepada setiap anggota kelompok yang melakukan pelanggaran
2) Jaringan

adalah kemampuan anggota-anggota kelompok/masyarakat selalu menyatukan diri dalam suatu pola hubungan yang sinergitis akan sangat besar yang berhubungan dengan kesukarelaan (voluntary), dan kebebasan (freedom).
a. Petani dengan Petani
b. Petani dengan Petani lain
c. Petani dengan Instansi Pemerintah
3) Kepercayaan

Kepercayaan adalah bentuk keinginan mengambil resiko dalam hubunganhubungan sosialnya yang didasari oleh perasaan yakin bahwa yang lain akan melakukan sesuatu seperti yang diharapkan dan akan senantiasa bertindak dalam suatu pola tindakan yang saling mendukung. Kepercayaaan meliputi hubungan sosial, harapan, dan interaksi sosial.

a. Hubungan Sosial : antara dua orang atau lebih, termasuk dalam hubungan ini adalah institusi yang dalam pengertian ini diwakili oleh orang.

b. Harapan : yang akan terkandung dalam hubungan itu, yang kalau direalisasikan tidak akan merugikan salah satu atau kedua belah pihak.

4) Reciprocity (Hubungan timbal balik) Reciprosity merupakan salah satu komponen Modal sosial yang diwarnai oleh kecenderungan saling bertukar kebaikan di 
antara individu-individu yang menjadi bagian atau anggota jaringan. Kriteria pengukuran dari reciprocity :

a. Tingkat Kepedulian Sosial

b. Sikap saling membantu

5) Nilai-nilai

Nilai-nilai adalah suatu ide yang dianggap benar dan penting oleh anggota komunitas dan diwariskan secara turun temurun. Kriteria pengukuran dari nilai-nilai
a. Kerja Keras
b. Kompetisi
c. Prestasi

\section{Teknik Analisis Data}

Metode analisis data yang digunakan dalam penelitian ini yaitu analisis deskriptif kemudian diinterpretasi untuk penarikan kesimpulan. Dengan metode penelitian kualitatif

\section{HASIL DAN PEMBAHASAN}

\section{Deskripsi Wilayah Penelitian}

Desa Tumani adalah sebuah desa yang terletak di wilayah Kecamatan Maesaan, Kabupaten Minahasa Selatan, Propinsi Sulawesi Utara. Terdiri dari 6 Jaga/Dusun. Dengan batas geografis wilayah:

Sebelah Utara

Sebelah Timur

: Desa Tumani Utara

Sebelah Barat

: Desa Kinalawiran

Sebelah Selatan

: Desa Lowian

: Desa Tumani Selatan

Wilayah ini berada pada ketinggian 800 meter di atas permukaan laut sehingga cocok untuk tanaman pertanian. Desa Tumani memiliki jumlah penduduk 1.120 orang dengan luas Wilayah $1.519 \mathrm{Ha}$.

\section{Gambaran Umum Kelompok Tani}

1. Kelompok Tani Esa Waya

Kelompok Tani Esa Waya terbentuk pada tahun 2006 yang beranggotakan 22 orang dengan pengurus 3 orang yakni Eddy J. Mamahit (Ketua), Heri Moonik (Sekertaris),
Donny Mamesah (Bendahara). Kelompok tani Esa Waya menanam tanaman padi ladang, jagung, kacang tanah, kacang kedelai, dan kacang brenebon. Kelompok tani Esa Waya juga menanam tanaman tahunan seperti coklat dan kelapa.

2. Kelompok Tani Sinar Mas

Kelompok Tani Sinar Mas terbentuk pada tahun 1997 dan beranggotakan 16 orang dengan pengurus 3 orang yakni Tertius Siso (Ketua), Max Lumentut (Sekertaris), Steven Rawung (Bendahara). Kelompok Tani Sinar Mas menanam padi ladang dan jagung.

\section{Karakteristik Responden}

1. Umur Responden

Tingkat Umur mempengaruhi kemampuan seseorang dalam melakukan aktifitas maupun konsep berpikir. Anggota kelompok tani yang memiliki umur muda tentunya memiliki kondisi fisik yang lebih kuat, keinginan untuk mencoba hal baru, serta memiliki daya berpikir yang lebih kreatif dibandingkan dengan yang berumut tua. Selain itu, tenaga kerja yang lebih tua cenderung lebih menjaga kesehatannya.

Tabel 1. Jumlah Responden menurut Tingkat Umur

\begin{tabular}{lccc}
\hline No & $\begin{array}{c}\text { Umur } \\
\text { (Tahun) }\end{array}$ & $\begin{array}{c}\text { Jumlah } \\
\text { Responden } \\
\text { (Orang) }\end{array}$ & $\begin{array}{c}\text { Persentase } \\
(\%)\end{array}$ \\
\hline \multicolumn{4}{c}{ Kelompok Tani Esa Waya } \\
\hline 1 & $<41$ & 1 & 9,09 \\
2 & $41-50$ & 7 & 63,64 \\
3 & $51-60$ & 2 & 18,18 \\
4 & $>60$ & 1 & 9,09 \\
\hline Jumlah & 11 & 100,00 \\
\hline \multicolumn{4}{c}{ Kelompok Tani Sinar Mas } \\
\hline 1 & 2 & 25,00 \\
2 & $41-50$ & 2 & 25,00 \\
3 & $51-60$ & 4 & 50,00 \\
\hline \multicolumn{4}{l}{ Jumlah } \\
\hline \multicolumn{4}{c}{ Data Primer, 2016. Diolah } \\
\multicolumn{3}{c}{ Hasil penelitian menunjukan bahwah usia } \\
responden berkisar antara 39-75 tahun Tabel \\
2 menunjukan bahwah usia responden pada
\end{tabular}


kelompok tani Esa Waya umum nya berkisar antara 41-50 tahun yaitu sebanyak 63,64\%

Sedangkan hasil penelitian pada kelompok tani Sinar Mas usia Responden berkisar antara 37 - 59 tahun Tabel 2 menunjukan bahwa usia responden pada kelompok tani Sinar Mas umumnya berkisar antara 51 - 60 tahun yaitu sebanyak 50,00\%

\section{Pendidikan Responden}

Tingkah laku individu atau seseorang sangat dipengaruhi oleh pendidikan yang telah dicapai. Begitu pula pada anggota kelompok tani tingkat pendidikan mempengaruhi prilaku anggota kelompok dalam kelompok tani. Tenaga kerja dengan pendidikan tinggi akan cenderung aktif dalam kelompok.

Tabel 2. Jumlah Responden Tingkat Pendidikan

\begin{tabular}{lccc}
\hline No & $\begin{array}{c}\text { Tingkat } \\
\text { Pendidikan }\end{array}$ & $\begin{array}{c}\text { Jumlah } \\
\text { Responden } \\
\text { (Orang) }\end{array}$ & $\begin{array}{c}\text { Persentase } \\
(\%)\end{array}$ \\
\hline \multicolumn{4}{c}{ Kelompok Tani Esa Waya } \\
\hline 1 & SMP & 4 & 36,36 \\
2 & SMA/SPG & 6 & 54,55 \\
3 & S1 & 1 & 9,09 \\
\hline Jumlah & 11 & 100,00 \\
\hline \multicolumn{4}{c}{ Kelompok Tani Sinar Mas } \\
\hline 1 & SMP & 4 & 50,00 \\
2 & SMA & 3 & 37,50 \\
3 & S1 & 1 & 12,50 \\
\hline Jumlah & 8 & 100,00 \\
\hline
\end{tabular}

Data Primer, 2016. Diolah

Tabel 2 menunjukan bahwa tingkat pendidikan responden pada Kelompok Tani Esa Waya yang paling banyak yaitu SMA sebanyak 6 responden $(54,55 \%)$, tingkat SMP sebanyak 4 responden $(36,36 \%)$ dan tingkat pendidikan $\mathrm{S} 1$ paling sedikit yaitu 1 responden $(9,09 \%)$.

Sedangkan tingkat pendidikan responden pada Kelompok Tani Sinar Mas yang paling banyak yaitu SMP sebanyak 4 orang $(50,00 \%)$, tingkat SMA sebanyak 3 responden $(37,50 \%)$ dan tingkat pendidikan S1 1 responden $(12,50 \%)$.

\section{MODAL SOSIAL}

1. Norma

a. Peraturan

Hasil penelitian menunjukan 11 responden $(100 \%)$ menyatakan bahwa di kelompok tani Esawaya menerapkan peraturan dalam kelompok taninya misalkan melakukan pertemuan rutin, tidak boleh lebih dari 3 kali tidak hadir dalam pertemuan, setiap anggota kelompok berkewajiban membayar iuran, anggota kelompok melakukan arisan, dan anggota kelompok yang melakukan pinjaman mengembalikan beserta bunganya, kelompok tani melakukan pemilihan pengurus baru setiap 2 tahun, dan setiap anggota kelompok wajib ikut serta saat ada kegiatan menggarap lahan bersama-sama Sedangkan pada kelompok tani Sinar Mas 8 reponden $(100 \%)$ mengatakan bahwa tidak lagi ada aturan sekarang namun dulunya ada peraturan-peraturan sama seperti kelompok tani Esa Waya tapi karena anggota kelompok sudah jarang bahkan tidak lagi rutin memberikan iuran, dan simpan pinjam sehingga kegiatan kegiatan kelompok tidak lagi berjalan baik, tidak ada lagi pertemuan rutin, dan anggota kelompok hanya terkumpul saat ada pembagian bibit dari pemerintah.

\section{b. Sanksi}

Hasil penelitian 11 responden (100\%) mengatakan bahwa terdapat sanksi dalam kelompok tani Esa waya misalkan jika pinjaman belum dikembalikan bunga pinjaman akan dilipat gandakan, dan jika ada anggota kelompok yang tidak ikut serta saat kegiatan bercocok tanam kelompok akan diberikan peringatan, kemudian jika masih melanggar akan ditindak lanjuti, jika melakukan pelanggaran bantuan bibit hanya akan diberikan setengah dari haknya, tetapi berdasarkan hasil wawancara belum pernah ada anggota kelompok tani Esa Waya yang dikenakan sanksi karena semua anggotanya tidak pernah ada yang melanggar aturan.

Sedangkan berdasarkan keterangan 8 responden $(100 \%)$ kelompok Tani Sinar Mas 
dulunya menerapkan sanksi kepada anggota kelompok yang melakukan pelanggaran aturan, namun semenjak tidak ada lagi aturan dalam kelompok dan anggota kelompok mengabaikan sanksi-sanksi yang diberikan contohnya uang pinjaman tidak lagi di kembalikan, dan jika dihimbau untuk berkumpul anggota yang tidak hadir tidak diberikan peringatan sehingga sampai saat ini dibiarkan begitu saja dan sudah tidak ada lagi sanksi yang diberlakukan.

\section{c. Keadilan}

Hasil penelitian menunjukan bahwa 11 responden $(100,00 \%)$ merasa bahwa pemimpin kelompok bertindak adil pada anggota kelompoknya, pada Kelompok Tani Esa Waya pemimpin kelompok bersifat adil kepada setiap anggota contoh nya dalam pembagian bibit, semua anggota diberikan bibit sama rata, pemimpin kelompok memperlakukan anggotanya dengan baik. Tidak ada keterangan yang berkaitan dengan keadilan memberi sanksi karena anggota kelompok tani Esa Waya tidak ada yang pernah melanggar aturan. Dan pemimpin kelompok tani Esa Waya selalu merespon dengan baik setiap pendapat atau masukan dari anggota.

Sedangkan pada kelompok tani Sinar Mas 5 responden $(62,50 \%)$ menganggap pemimpin kelompok bersikap adil contohnya dalam pembagian bibit, dan semua yang melakukan pelanggaran diberikan sanksi tetapi para anggota kelompok yang melakukan pelanggaran pada umumnya mengabaikan sanksi yang diberikan oleh pemimpin kelompok. Dan 3 responden (37,50\%) menganggap pemimpin kelompok kurang adil dengan alasan 1 responden diantaranya adalah anggota yang tidak pernah melakukan pelanggaran kemudian merasa kurang adil karena anggota lainnya yang melakukan pelanggaran meminjam uang kas dan tidak mengembalikan uang pinjaman beserta bunganya dan sampai saat ini dibiarkan begitu saja oleh pemimpin kelompok, dan yang tidak hadir saat ada pertemuan juga tidak dibiarkan, sehingga kelompok Sinar Mas sudah tidak lagi berkembang. 2 responden lainnya yang merasa kurang adil dengan alasan karena mereka jarang diberitahu jika ada bantuan bibit dari pemerintah.

\section{Jaringan}

\section{a. Petani dengan Petani}

Hasil penelitian menunjukan bahwa berdasarkan pernyataan 11 responden (100\%) antar kelompok tani Esa Waya memiliki jaringan yang kuat yaitu hubungan-hubungan sesama anggota dalam kelompok terjalin dengan baik, misalkan pada pertemuan rutin yang diadakan setiap hari selasa anggota kelompok selalu berkumpul untuk berinteraksi tentang bercocok tanam dan hasil panennya.

Sedangkan dalam kelompok tani Sinar Mas 6 responden $(75 \%)$ menyatakan bahwah jaringan antar angota kelompok cukup baik, karena berdasarkan hasil wawancara saat ini kelompok tani Sinar Mas sudah tidak lagi melakukan pertemuan rutin dan anggota kelompok sudah jarang terkumpul saat dihimbau untuk mengadakan pertemuan, dengan alasan masing-masing. Dan 2 responden $(25 \%)$ yang menjawab Kelompok tani Sinar Mas memiliki jaringan antar kelompok yang baik adalah mereka yang rajin berkumpul jika ada pertemuan dan selalu berusaha menjalin hubungan baik dengan anggota kelompok.

\section{b. Petani dengan Petani Lain}

Hasil penelitian menunjukan bahwa 11 responden (100\%) kelompok tani Esa waya memiliki jaringan antara petani dalam kelompok dengan petani dalam kelompok tani lain/petani lain memiliki interaksi yang baik. Berdasarkan wawancara yang di dapat interaksi petani kelompok Esa waya sangat baik karena petani dari kelompok tani lain selalu meminta informasi atau bertanya tentang bibit yang bagus atau bagaimana kelompok tani Esa Waya bercocok tanam karena hasil-hasil produksi dari kelompok 
tani Esa waya sangat baik, dan dari situlah terjadi interaksi yang baik antara petani Esa waya dan petani di luar kelompok tani.

Sedangkan dari kelompok tani Sinar mas 8 responden $(100 \%)$ memiliki jaringan yang baik dengan anggota kelompok lain dengan alasan yang berbeda dengan kelompok tani Esa waya, kelompok tani Sinar mas memiliki interaksi yang baik di luar kelompok. Namun dari hasil wawancara yang di dapat pada kelompok tani Sinar Mas yaitu petani dalam kelompok berinteraksi dengan petani diluar kelompok dikarenakan adanya pertemuan semua kelompok tani di desa Tumani atau tidak disengajakan bertemu di luar rumah dan berbincang-bincang dan bertukar pikiran tentang hal-hal yang ada dalam kelompok tani dan hal-hal di luar kelompok tani.

c. Petani dengan Instansi Pemerintah

Hasil penelitian menunjukan bahwa 11 responden (100\%) kelompok tani Esa Waya memiliki hubungan yang baik dengan instansi pemeritah baik pemerintah di Desa yaitu hukum tua dan perangkatnya dimana hukum tua Desa Tumani tergabung dalam kelompok tani Esa Waya sebagai sekertaris kelompok tani Esa Waya. Begitu juga dengan Balai Penyuluhan Pertanian Perikanan dan Kehutanan BP3K Kecamatan Maesaan kelompok tani Esa Waya memiliki jaringan yang baik, BP3K selalu rutin memberikan bantuan bibit kepada kelompok Esa Waya, dan beberapa anggota bersama-sama mengambil bantuan bibit di kantor BP3K, dan setiap ada perubahan data kelompok selalu di laporkan ke BP3K.

Sedangkan 8 responden (100\%) kelompok tani Sinar Mas juga memiliki jaringan yang baik dengan instansi pemerintah Desa dan $\mathrm{BP} 3 \mathrm{~K}$ rutin memberikan bantuan bibit kepada anggota kelompok, namun berdasarkan hasil wawancara hanya ketua kelompok yang berkomunikasi dengan BP3K, anggota kelompok mengambil bantuan bibit langsung ke rumah ketua kelompok.
3. Kepercayaan

a. Hubungan Sosial dengan Institusi Pemerintah

Hasil penelitian menunjukan bahwa 11 responden (100\%) kelompok tani Esa Waya memiliki hubungan sosial yang baik dengan pemerintah maupun bantuan-bantuan pemerintah mampu mensejahterahkan anggota kelompok tani, anggota kelompok tidak perlu lagi membeli bibit, dan bantuan bibit tersebut diolah dengan baik sehingga menghasilkan produksi serta hasil panen yang baik untuk setiap anggota maupun untuk kelompok, karena bantuan bibit tidak hanya dipakai masing-masing anggota tapi juga ada bibit yang dipakai untuk menanam bersama seluruh kelompok dan kemudian hasil panennya dimasukan ke dana kas kelompok.

Sedangkan 8 responden (100\%) kelompok tani Sinar Mas juga menganggap bahwa hubungan sosial yang terjalin dengan instansi pemerintah ini mampu mensejahterahkan masing-masing anggota dengan pembagian bibit secara rutin

\section{b. Harapan}

Hasil penelitian menunjukan bahwa 11 responden $(100,00)$ memiliki harapan untuk bertahan hidup dengan usaha tani, harapan yang terkandung dalam hubungan sosial yang dibangun ini tidak akan merugikan salah satu pihak bahkan kedua belah pihak, dengan tergabung dalam kelompok tani Esa waya anggota kelompok mampu memenuhi kebutuhan hidup keluarganya melalui bercocok tanam, bantuan pemerintah, dukungan sesama anggota kelompok, serta bantuan pinjaman dari kas kelompok sangat membantu untuk modal usaha bagi anggota kelompok. Dan anggota kelompok akan mampu bertahan hidup dengan bercocok tanam.

Sedangkan 7 responden $(87,50 \%)$ Kelompok tani Sinar Mas juga memiliki harapan untuk bertahan hidup dengan usaha tani, harapan yang terkandung dalam hubungan sosial yang dibangun ini tidak akan merugikan salah satu pihak bahkan kedua 
belah pihak, dengan tergabung dalam kelompok tani Sinar mas anggota mampu memenuhi kebutuhan hidup, namun kurang adanya kekompakan dengan anggota kelompok. Dan 1 responden (12,50\%) merasa tidak akan mampu memenuhi kebutuhan hidup melalui usaha bercocok tanam dan responden ini adalah anggota kelompok yang mempunyai usaha minimarket dia menganggap usahanya yang akan mampu memenuhi kebutuhan hidupnya.

\section{Reciprocity (Hubungan Timbal Balik)}

a. Tingkat Kepedulian Sosial

Hasil penelitian menunjukan bahwa 11 responden (100\%) anggota kelompok tani Esa Waya memiliki kepedulian sosial yang tinggi, berdasarkan hasil wawancara anggota kelompok lainnya akan langsung memperhatikan jika salah satu anggota mengalami kesulitan dalam usaha taninya kemudian memberi solusi dan bukan hanya menjadi pembahasan bersama dua orang atau lebih tetapi juga menjadi pembahasan kelompok, karena permasalahan salah satu anggota akan dirundingkan bersama dalam pertemuan dengan kelompok dan semua anggota bertukar pikiran serta memberikan pendapat, sehingga mendapat solusi bersama.

Sedangkan 8 responden $(100 \%)$ kelompok tani tani Sinar Mas juga mengatakan memilki kepedulian sosial dengan alasan jika ada angota kelompok yang menghadapi masalah anggota lainnya menunjukan simpati dan kadang bertanya permasalahannya sambil memberikan solusi.

\section{b. Sikap Saling Membantu}

Hasil penelitian menunjukan bahwa 11 responden $(100,00 \%)$ kelompok tani Esa Waya saling tolong-menolong dengan anggota kelompok lain yang memerlukan pertolongan contohnya jika ada anggota yang tanaman padinya menjadi merah (mentek) anggota lainnya membantu memberi racun, saling meminjamkan sapi kepada anggota yang membutuhkan, bersama sama menyiram tanaman kakao, jika ada yang kelebihan bibit diberikan kepada yang anggota lainnya, dan anggota yang sudah panen duluan membantu anggota yang tertinggal dalam penanaman (terlambat).

Sedangkan kelompok tani Sinar Mas 8 responden $(100 \%)$ megatakan kurang adanya sikap saling membantu, hanya saling memperhatikan dan memberi solusi tapi kurang memberikan bantuan atau pertolongan langsung, mereka fokus dengan usaha taninya sendiri

\section{Nilai-Nilai}

\section{a. Kerja Keras}

Hasil penelitian menunjukan 11 responden $(100 \%)$ menyatakan bahwah tergabung dalam kelompok serta bercocok tanam dalam kelompok tani Esa Waya menimbulkan sikap pekerja keras bagi anggotanya bantuan pemerintah, perlakuan yang adil dari pemimpin kelompok serta kekompakan kelompok menjadi penambah semangat anggota dalam usahanya, kepedulian sesama anggota yang saling membantu dengan yang lainnya membuat semua anggota menjadi rajin dan pekerja keras.

Sedangkan 8 responden $(100 \%)$ anggota kelompok tani Sinar Mas juga merasa memiliki semangat kerja keras tapi tidak dalam kelompok melainkan bekerja keras untuk kepentingan, mata pencaharian pribadi.

\section{b. Kompetisi}

Hasil penelitian menunjukan bahwah 11 responden (100\%) anggota kelompok tani Esa Waya memiliki semangat kompetisi mereka selalu melakukan yang terbaik dalam usaha taninya, terus mencari tahu kekurangan yang dimiliki dan berusaha memperbaiki kekurangan untuk meningkatkan produktifitas agar tetap unggul dari kelompok lainnya.

Sedangkan 5 responden $(62,50 \%)$ anggota kelompok tani Sinar Mas merasa jarang untuk berkompetisi bahkan 2 responden $(25 \%)$ responden sama sekali tidak merasakan semangat berkompetisi, dari hasil 
wawancara mereka hanya bercocok tanam untuk sekedar mendapatkan penghasilan dan tidak harus melebihi kelompok lainnya, yang terpenting hanyalah usaha taninya tetap berjalan. Dan 1 responden merasa bahwa dia melakukan usaha tani dengan sebaik mungkin agar unggul dibandingkan yang lainnya.

\section{c. Prestasi}

Hasil penelitian menunjukan bahwah 11 responden (100\%) anggota kelompok tani Esa Waya merasa pernah mencapai prestasi kerja, yaitu dimana saat seluruh anggota kelompok bercocok tanam bersama-sama pada tahun 2015 lalu mereka menanam Jagung dan Padi ladang, saat itu hasil panen jagung sebanyak 6 Ton dan hasil panen Padi ladang sebanyak 45 bantal (60kg per bantal) dan anggota kelompok sepakat bahwah seluruh hasil pendapatan kelompok ini di masukan kedalam uang kas kelompok. Untuk dijadikan sumber pinjaman anggota kelompok. Selain itu pada tahun 2014 kelompok tani Esa Waya pernah diutus Jakarta namun karena faktor usia dari ketua kelompok yang sudah berusia 73 tahun, maka perwakilan daerah digantikan oleh kelompok tani lainnya yang juga unggul.

Sedangkan 8 responden $(100 \%)$ kelompok tani Sinar Mas merasa tidak memiliki prestasi kelompok karena kelompok tani ini tidak pernah bercocok tanam bersama, dan sumbangan bibit dari pemerintah dibagikan ke perorangan untuk diolah masing-masing.

\section{KESIMPULAN}

1. Modal sosial kelompok Tani Esa Waya berdasarkan variabel norma kelompok tani esa waya menerapkan peraturan-peraturan dalam kelompok dan bagi anggota yang melakukan pelanggaran akan diberikan peringatan kemudian dikenakan sanksi secara adil ke semua anggota, namun belum pernah ada anggota kelompok yang melakukan pelanggaran.

Sedangkan pada Kelompok Tani Sinar Mas tidak ada lagi peraturan sekarang namun dulunya pernah ada, karena pelanggaran pelanggaran yang dilakukan anggota kelompok dan sanksi sanksi yang diberikan tidak dipatuhi sehingga semakin lama kelompok tidak lagi berjalan baik.

2. Modal sosial berdasarkan jaringan Kelompok Tani Esa Waya memiliki jaringan yang baik dengan sesama anggota kelompok, anggota kelompok lain maupun instansi pemerintah, contohnya keaktifan dalam pertemuan kelompok, adanya komunikasi dengan anggota kelompok lain tentang bercocok tanam, dan kerjasama dengan BP3K dalam penyaluran bibit

Sedangkan Kelompok Tani Sinar Mas kurang memiliki jaringan yang baik dengan sesama kelompok karena sudah jarang terkumpul saat ada pertemuan sehingga pertemuan rutin dihapuskan dan hanya terkumpul saat pembagian bibit, untuk komunikasi dengan kelompok lain terjadi saat diadakan pertemuan seluruh kelompok tani desa Tumani.

3. Hubungan sosial dalam kelompok dan dengan instansi pemerintah mampu meningkatkan kesejahteraan anggota maupun Kelompok Tani Esa Waya, anggota kelompok dimudahkan dengan bantuan bantuan bibit dari pemerintah, dan bantuan dan dukungan dari anggota kelompok lainnya, dan dari hasil panennya mereka mampu memenuhi kebutuhan hidup

Sedangkan dalam Kelompok Tani Sinar Mas hubungan sosial yang terjalin dengan instansi pemerintah ini mampu mensejahterahkan masing-masing anggota dengan pembagian bibit secara rutin, dan bercocok tanam dalam kelompok juga mamp memenuhi kebuthan hidup sebagian besar anggota kelompok.

4. Hubungan timbal balik yang baik terjalin didalam Kelompok Tani Esa Waya mereka saling memperhatikan dan anggota yg menghadapi permasalahan menjadi perundingan bersama kemudian diberi solusi bahkan turut menolong membagikan bibit meminjamkan sapi, bekerja sama dalam usaha tani kelompok dan bantuanbantuan lainnya

Sedangkan pada Kelompok Tani Sinar Mas mereka juga saling memperhatikan, bersimpati, bertukar pikiran dan memberi 
solusi tapi kurang memberikan pertolongan langsung, anggota kelompok hanya fokus dengan usaha taninya masing-masing.

5. Tergabung dalam Kelompok Tani Esa Waya mampu menjadikan anggota Kelompok Tani Esa Waya memiliki nilai kerja keras, kompetisi, dan prestasi, kerjasama kelompok, kepedulian kelompok dan usaha-usaha yang terjadi didalamnya membuat mereka memiliki nilai kerja keras yang tinggi, selalu meningkatkan produktifitas agar tetap unggul dan mencapai prestasi prestasi yang diharapkan bahkan mengasilkan panen yang memuaskan

Sedangkan anggota Kelompok Tani Sinar Mas juga memiliki nilai kerja keras namun hanya untuk kepentingan pribadi bukan untuk kesejateraan kelompok, mereka bercocok tanam untuk sekedar memenuhi kebutuhan hidup tidak untuk berkompetisi menjadi yang terbaik sehingga prestasi kelompok pun sulit diraih.

Modal Sosial telah mampu meningkatkan eksistensi serta kekompakan Kelompok Tani Esa Waya karenanya modal tersebut diperhitungkan keberadaannya dalam kelompok tani dibandingkan Kelompok Tani Sinar Mas yang unsur-unsur modal Sosial didalamnya sudah berkurang bahkan tidak ada lagi sehingga membuat kelompok ini kurang aktif. Disamping itu, ada unsur lain sebagai penunjang Kelompok Tani Esa Waya adalah tingkat umur yang lebih muda, dan tingkat pendidikan yang lebih tinggi, anggota kelompok yang tergolong muda memiliki kondisi fisik yang lebih kuat dan lebih kreatif dan anggota kelompok dengan tingkat pendidikan yang lebih tinggi akan cenderung aktif dalam kelompok dibandingkan Kelompok Tani Sinar Mas yang anggotanya berada pada tingkat umur lebih tua dan tingkat pendidikan yang lebih rendah.

\section{SARAN}

Berdasarkan hasil penelitian bahwa Kelompok Tani Esa Waya sudah memiliki modal sosial dilihat dari kekompakan dalam kelompok serta kerjasama yang terjalin membuat aktifitas dalam kelompok berjalan dengan baik maka disarankan agar Kelompok Tani Esa Waya terus mempertahankan bahkan meningkatkan produkfitas dan kerjasama yang dimiliki agar dapat menjadi contoh bagi kelompok tani lainnya di Desa Tumani.

Kelompok Tani Sinar Mas Sebagai salah satu kelompok tani kurang aktif di desa Tumani agar supaya mengevaluasi kembali kelompoknya, pemimpin kelompok bersikap tegas merangkul para anggotanya, dan anggota kelompok diharapkan membangkitkan kembali semangat bekerja sama bukan hanya memikirkan kepentingan pribadi tapi juga kelompok. Diadakan lagi pertemuan rutin agar semua permasalahan kelompok dapat dibahas bersama-sama.

\section{DAFTAR PUSTAKA}

Anonim. 2011. Kepercayaan, Modal Sosial, Cegah Bencana http://nasional kompas.com. Diakses pada tanggal 29 Maret 2016

Badan Pusat Statistik. Minahasa Selatan. 2013. Jumlah Petani menurut Sektor/Subsektor dan Jenis Kelamin di Kabupaten Minahasa Selatan ST2013

Creswell, 1998. Qualitative Inquiry: Choosing Among Five Traditions. Sage Publication

Damima, V. 2001. Dinamika Kelompok Tani Padi Sawah di kecamatan Tondano Kabupatan Minahasa (Studi Kasus Kelompok Tani di Desa Tataaran 1. Skripsi Fakultas Pertanian Universitas Sam Ratulangi Manado Tani dalam Implementasi Prima Tani di Sumatra Selatan. Jurnal Analisis Kebijaan Pertanian. Vol 5. 
Fukuyama, Francis, 2002. The Great

Disruption :Hakikat Manusia dan Rekonstruksi Tatanan Sosial, Yogyakarta : CV Qalam

Hasbullah, 2006. Social Capital (Menuju keungguln Budaya Indonesia) Jakarta ;MR-United Press

Lawang, Robert M.Z, 2005. Kapital Sosial dalam perspektif Sosiologik, FISIP UI Press : Depok

Putnam, Robert, 1993. Social Capital. Pricenton University : Pricenton
Saragih, Bungaran. 2004. Pertanian Mandiri : Membangun Pertanian Perspektif Agribisnis. Bogor : Penebar Swadaya.

Suharto, E. 2007.Modal Sosial dan Kebijakan Publik

Suswono, 2013. Pedoman Pembinaan

Kelompok Tani dan Gabungan

Kelompok Tani. Kementrian

Pertanian.Jakarta

Hermanto, 2007. Rancangan Kelembagaan 